\title{
An Assessment of Rural Households Livelihood Assets of Wolaita Zone, Ethiopia
}

\author{
Deneke Dana Dabara $(\mathrm{PhD})$ \\ Economic Geography, Wolaita Sodo University, Ethiopia
}

\begin{abstract}
The aim of this study was to assess existing rural household's livelihood assets in Wolaita zone, Ethiopia. The demographic and socio-economic data were collected from 300 randomly selected rural households. The basic data for the study were obtained from both primary and secondary sources. The collected data were analysed by using both qualitative and quantitative methods. The study revealed land is one of the basic economic assets of and livelihood sources for agrarian rural people but the size of the plots is so small in the study area. The findings concerning the livelihood assets that had been developed were presented in line with the three livelihood assets, namely human, natural, and financial capital, all of which were shown to have negative results. The abovementioned livelihood assets in the study area were weak. From the human assets section, 41percent of the study population had not achieved a school educational qualification. About half percent of respondents said their soil was not fertile from the physical assets perspective. A large number of respondents did not practise saving on account of their low daily-income status. Thus concerning body including government should strongly work on the discussed rural assets built up to minimize the rural household's livelihood problems in study area.
\end{abstract}

Keywords: Wolaita, rural, assets, human, natural, financial, households, livelihood

DOI: $10.7176 /$ RHSS/10-5-01

Publication date:March $31^{\text {st }} 2020$

\section{INTRODUCTION}

Of all the less-developed regions of the world, Sub-Saharan Africa is the most severely affected region in terms of livelihood problems. This is due to, amongst others, the unprecedented population growth, the poor systems of administration, the prevalence of civil wars, technological inefficiency, environmental degradation, climatic change, unsatisfactory and tenure systems and policies, and unstable social organization. Food shortage is significantly worse in states with agricultural systems that are more susceptible to variations in rainfall and temperature and where the livelihood of a large proportion of the population depends on agriculture (FAO, 2018). According to (Kgathi, Nigwenya, and Wilk, 2007), achieving sustainable socio-economic growth and poverty reduction remains the key challenge facing this African region. Despite the fact that rural development has been central in the development schemes of most developing countries, there is little evidence that much has changed in recent years. The region comprises more than 13 percent of the world population (World Bank, 2016) and the region's population is exceptionally poor and growing very fast (by $3 \%$ per annum) which would lead to the doubling of the population size in about every 23 years.

Ethiopia is part of this region and does not escape from the problems mentioned earlier. As a result, the livelihoods of rural people are endangered in Ethiopia. Because of the limited livelihood options of the rural communities and their dependence on the size and productivity of the farmland, the livelihood problem is more severe in rural areas than in urban areas. This study focuses on investigating existing rural livelihood assets and its effects on rural livelihoods.

In Ethiopia, rapid rural population growth and its resulting livelihood problems have been putting immense pressure on the natural resource asset base, leading to a gradual deterioration in both quantity and quality. As other studies have revealed, population growth further leads to the unnecessary exploitation of natural resource assets as in the case of deforestation for farming and settlement purposes, short fallow periods, the cultivation of rangelands, and land fragmentation, all of which have a direct and adverse effect on agricultural output (Tefera, 2009; Tegegne, 2014). Because of the low agricultural productivity, large numbers of rural communities are being exposed to livelihood problems.

According to Chambers and Conway (1992), livelihood comprises of the capabilities, assets (including both material and social resources), and activities required for a means of earning a living. A livelihood is sustainable when it can cope with, and recover from, stresses and shocks, and maintain or enhance its capabilities and assets both now and in the future, while not undermining the natural resource base (Chambers and Conway, 1992; Swedish University of Agricultural Sciences (SLU), 2003; Mwassa, 2012). Hence livelihood security is achieved when the livelihood provides adequately for both the current and the next generations throughout all seasons and times. A household can achieve this security by achieving one or a combination of livelihood outcomes, some of which could be ownership of land, stable employment, income and grazing rights.

Livelihood comprises five major components of assets: natural capital, physical capital, human capital, financial capital and social capital (Swift, 1998). An 'asset' can further be described as stocks of capital that can 
be utilized directly or indirectly to generate the means of survival of the household or to sustain its material wellbeing. Natural capital comprises the land, water, and biological resources that are utilized by rural people to generate their means of survival. Physical capital consists of capital that is created by economic production processes, including buildings or shelters, roads, and tools. Financial capital refers to stocks of money to which the household has access, and human capital refers to the labour available to the household, and is based on the education, skills, and health factors pertaining to the household.

From the Ethiopian rural household context, Deneke (2008:31) attempted to define rural livelihood as follows:

"Livelihood is the ability to establish access to productive resources such as land, livestock, agricultural inputs, access to health centres and education, access to markets and family labour, combined to produce livelihood security or the well-being of the family".

According to the above definition, the livelihood assets of an Ethiopian rural household is mostly determined by the presence of land, livestock, access to education, a health centre and a market centre, agricultural inputs, and the productivity of the family members.

Ethiopia is the second-most populous country in Africa, and its annual per capita income of around US \$150 is the lowest on the continent. About 39 percent of the population lives below the poverty line, and the extent and severity of poverty are much higher in the rural areas with 45 percent of the people living below the poverty line. The land area, at over 1.1 million square kilometres, is among the largest in Africa, but only 15 percent is arable (cultivated land). In addition, the cultivable land of Ethiopia amounts to only 35 percent but only 40 percent of this is cultivated (FAO, 2016). The size of the landholdings is less than one hectare per household and in many cases, it is as low as 0.25 hectares per household (FAO, 2004; World Bank, 2011).

Wolaita zone is one of the most densely-populated areas in Ethiopia. It's found in southern part of the country with an average density of 375 persons per square kilometre (Deneke, 2008). The average annual per capita income of the study area is around the US $\$ 100$ mark, which is below the country average. In addition to this, the average maximum and minimum landholding area is 0.5 hectare and 0.125 hectares respectively (Talemos, 2007; WZFEDD, 2018). From the researcher's close observations, most people in the Wolaita zone live in rural areas and are dependent upon their subsistence farming activities. As the rural population numbers in the area increase over time, the expected result would be an increment in the demand for food, resulting in the degradation of the existing farmland and the expansion of agricultural land at the cost of natural resource assets. Owing to the rapid increase in the number of farmers in the study area, the area of an individual's landholding would also decrease.

This has important repercussions, given the diminutive landholdings and the poor agricultural technology in the area, which in their turn aggravate the rural livelihood problems of the zone. Thus, the research is intended to assess existing rural household's livelihood assets and to indicate proper strategies in the Wolaita zone.

\section{METHODS}

\subsection{Study Area Setting}

The Wolaita zone (the study area) is one of fourteen zones of the Southern Nation Nationalities Region (SNNPR)of Ethiopia, which is one of nine other regional states of the country. The capital of the Wolaita zone, Wolaita Sodo, is located about $330 \mathrm{kms}$ away from Addis Ababa, the capital of Ethiopia to the south. The Wolaita zone lies between $06^{\circ} 51^{\prime}$ and $07^{\circ} 35^{\prime} \mathrm{N}$ latitudes, and $37^{\circ} 46^{\prime}$ and $38^{\circ} 1^{\prime} \mathrm{E}$ longitudes (Figure 1).

\subsection{Sampling Frame and Techniques}

The researcher was determined to use head of households as the sample frame from the 2016 populations and sample survey of the zone report. The total number of households under study was 5,926 persons and about 300 household heads were randomly selected as the sample for the study.

According to Gay and Peter (2000:134), for descriptive research it is common to sample 5 percent to 10 percent of the population although this range will change with the size of the population studied. If the total size of the population is around 1500, 10 percent should be sampled and if greater than 2000,5-10percent should be sampled. But the total population of this study area was nearly 6000 as stated in the above paragraph. Therefore, the researchers used 5.06percent from the above mentioned population and 300 rural households were selected as sample size for this study. And also the necessary data were collected through a questionnaires, focus group discussions, observations, and interviews.

\subsection{Methods of Data Analysis}

The data drawn from the questionnaires were analysed by descriptive statistical techniques such as percentiles, averages, and ratios. The data obtained through interviews, focus group discussions and observation were analysed in a qualitative way. 


\section{RESULTS AND DISCUSSION}

\subsection{Introduction}

This study was aimed to assess the household livelihood assets such as the human, natural, and financial assets to determine how crucial they were in realizing the sustainable livelihood outcomes for the respective rural communities. Thus, based on the livelihood framework, the three categories of assets were examined during the fieldwork phase of the research.

\subsection{Human Capital}

As different literature sources indicate, human capital consists of the skills, knowledge and ability to exert physical and mental efforts for production processes and good health that enables an individual or household to pursue different livelihood strategies in order to achieve desirable livelihood outcomes (Scoones, 2009; Bennet, 2010). In this study, human capital was assessed from the point of view of household labour requirements and level of education.

\subsubsection{Source of Labour in Study Area}

The respondents were asked to indicate their sources of labour for their rural economic activities or farming activities.

As presented in Table 1, the majority of households in the study area depended on family labour to meet the labour requirements of their various livelihood strategies. About 69 percent of respondents in Damot Sore and almost 80 percent of the respondents in both Damot Gale and Damot Pulasa were dependent exclusively on family labour to meet the labour demands of their farming activities. Households using hired labour were insignificant in the study area: for instance, 2.1 percent in Damot Sore; 3.4 percent in Damot Gale and 4.3 percent in Damot Pulasa used hired labour for their livelihood strategies. However, 29.2 percent in Damot Sore, 17 percent in Damot Gale and 16 percent in Damot Pulasa used both hired and family labour. Generally, in the study area, three-quarters of the respondents indicated that family members were their source of labour. In the study area, hired labourers were used mainly and only during the harvesting season. But the quality of labour was dependent on other social criteria such as the health status of the respondent, the level of educational attainment, that person's perceptions towards work and to the skills of individuals.

\subsubsection{Educational Attainment of Study Population}

Education is one of the tools which sharpens the knowledge and skills of human beings enabling them to exploit the existing resources from the earth's surface and to improve their lives through safe and adequate means. Education is also one of the factors affecting the householder's access to a source of labour and to labour quality. Educated people are more skilled or potentially able to adopt new ideas and technology easily and have greater access to employment as opposed to the uneducated members of a community.

In this next section of the paper the educational attainment of household heads is discussed.

As Table 2 indicates, 41 percent of the household heads sampled in this study could not read and write. The study districts showed variations in their literacy rates. For instance, in Damot Sore woreda, more than half of the people were illiterate, while in the Damot Gale and Damot Pulasa woredas, the number of illiterate people was similar, with 36 percent in each case. In terms of the number of household heads who had attended secondary schools, the Damot Gale woreda had a figure of 29 percent, whereas the woredas at Damot Pulasa and Damot Sore presented with figures of 18 percent and 15.6 percent respectively. In general, of the total respondents in the study area, nearly 12 percent were diploma- and above certificate holders. This low literacy rate for the study area has its own negative impacts on the labour supply, labour quality and labour productivity and also resulted in the low livelihood security of the study community.

\subsection{Natural Capital}

As the various literature sources indicate, particularly in terms of economic theory, physical capital is one of the primary factors of production, including inputs for production processes and natural resources such as human labour and land respectively. Natural capital is directly related to human and financial capital. Most of the productivity directed at agrarian rural people's' livelihoods is directly dependent on the availability and adequacy of natural capital such as access to farmland and its size, the fertility of the soil, the natural vegetation and climatic factors. Where the provision and quality of these resources are insufficient, the lives and livelihoods of the rural households are highly threatened.

In the following part of this research, aspects of the physical capital are discussed in the context of the sampled community.

\subsubsection{Size of Landholding}

One of land-related problem in the study area has been the declining size of the farmland over time. As presented in Table 3(present it on the next page), the sizes of the individual landholdings of the Wolaita zone are showing a continuous decline as time progresses. This is on account of the rapid population growth and the formation of additional new households that demand farmland from year to year. The distribution of the individual landholdings 
of the rural households is presented in the said table for the periods prior to the 10-years-ago mark, prior to 20 years-ago mark, and prior to the 30-years-ago mark. As the data show, during the period prior to the 30-years-ago mark, about 40percent of the household heads owned more than two hectares of land. But the percentage of household heads in this category of landholding had declined to 22 percent after the 10-years-ago mark; and again, this proportion had decreased to 10percent after the 20-years-ago mark. Also, currently, the proportion of households owning more than two hectares in the study area amounted to five percent. Contrary to this category, households owning less than 0.25 hectares amounted to 2.4 percent prior to 30 -years- ago mark and this value rose to 21 percent prior to the 10 -years-ago mark of their having been in the study area. Besides these values, according to the surveyed data, the proportion of households owning less than 0.25 hectares of farmland has dramatically increased to 44 percent in the present time.

Of the three sampled study areas, the decrease in the landholding size over time in the Damot Sore woreda has proved to have been the most serious. Individual households which prior to the 30 -years-ago mark had owned more than two hectares of farmland constituted 53 percent of the sampled population in this woreda, while households which possessed less than 0.25 hectares at that time had constituted only one percent of the sampled population. However, at the present time, only $3.1 \%$ of the individuals in the Damot Sore woreda now own more than two hectares of farmland. As a further contrast, the number of households holding less than 0.25 hectares of farmland has skyrocketed and now makes up 47percent of the total sampled population of this woreda. This means that there has been a rapid decrease in the size of the landholdings in this particular woreda (See Table 3).

On the other hand, changes in land size with time have been relatively but also significantly sluggish in the Damot Pulasa woreda. The rural average for the landholding distribution of the individual households in the study area prior to the 30-years-ago mark was 1.75 hectares and it became 1.35 hectares prior to the 20 -years-ago mark. The variation amounted to 0.4 hectares in the 10-year gap. Also, as the surveyed data reveals, the average landholding size in the Wolaita zone prior to the 10-years-ago mark, and that for the recent (current) situation amounted to 1.0 and 0.59 hectares respectively (Table 3 ).

To sum up, the landholdings of households and their access to the land for their farming activities has been in a state of uninterrupted change. A comparison of the size of the present landholdings with those dating back 30 , 20 and 10 years back, reveals a considerable decline in the size of farmland through time(see Table 3)

\subsubsection{Soil and its Fertility}

Soil is one of the basic natural assets for the productivity of the agricultural sector and for people whose livelihoods depend on farming. Agricultural productivity depends on, amongst others, the soil texture, the size of the soil particles, soil fertility, and the water-holding capacity of the soil. From these different criteria, which are used for distinguishing between the qualities of the respective soils, the researcher used the fertility of the farmland soil of the rural households of the study area for this paper since the fertility of the soil is one of the strong determinants affecting food security and the livelihood conditions of the rural community.

As the study reveals, 48 percent of the study population indicated that they considered their soils to be infertile (Table 4). Also, only 24 percent and 12 percent of the study population perceived that their farmland plots were fertile and very fertile respectively. Besides these observations, information gleaned from the peasant householders, during the focus group discussion phase, revealed that soil fertility is perceived as a serious problem leading to low harvest yields from their farmlands from year to year, and also that in the light of the shortage of land, the main cause of soil infertility is the frequent cultivation of farmland without fallow periods.

\subsubsection{Natural Vegetation Coverage}

Owing to the rapid population growth in the Wolaita area, indigenous forest growth and coverage were virtually nullified and, instead, replaced by exotic forests. Furthermore, there was no open land for natural vegetational coverage. However, there are still vestiges of some of the indigenous types of forests in some sacred areas, along river banks and around religious institutional compounds. The absence of natural vegetational coverage has its own impacts on the livelihood situation of the poor rural households. Also, because of the limited vegetational coverage, the local environment is being degraded over time, resulting in the drying up of swampy areas, streams, and rivers during the dry season.

The eucalyptus is an exotic tree that is dominant in the Wolaita area. It is also planted along the margins of the farmlands of each rural household. Some of the agricultural plantations/orchards of mango trees, avocado trees, bananas and orange trees also make the area green. But during the focus group discussion phase, the elder peasants indicated that the absence of natural vegetation and the open land in the rural areas were seriously affecting their livelihoods in that they were prevented from rearing livestock, which is very important for gaining access to milk and milk products. Moreover, they were of the opinion that animal rearing is essential for maintaining soil fertility, which depends on animal waste 1(e.g. dung/manure)being applied to their plots of land. Thus, the absence of or a change in the natural vegetational cover in the rural areas has multifaceted negative impacts on the livelihoods of the rural communities in the Wolaita zone. 


\subsection{Financial Capital}

The financial issue is the blood vessel for every socio-economic activity performed by a given community whether in an urban or a rural context. For rural communities, accessing farmland; sending children to school; feeding a family; getting medical treatment from health centres; procuring basic consumer goods such as clothing, sugar, and salt, from markets; the purchasing of agricultural inputs such as fertilizers, pesticides and selected seeds; and finance and gaining access to savings; - all become a crucial part of a rural community's livelihood. In this study, the welfare of a community in terms of its financial capital is assessed by looking at, amongst others, its access to credit services, livestock production and the incomes of rural households.

\subsubsection{Access to Credit Services and Savings}

A household's access to credit services and savings is a good indicator of its financial capital status. Here, respondents were asked whether they had borrowed money during times of food insecurity and livelihood challenges and what their sources of credit were. The respondents were also asked whether they had ever saved money and their means of saving.

As presented in Table 5, of the total of 300 sampled household heads, about 60 percent (181) of the study respondents replied that they had received credit during poor seasons and that it had been placed at their disposal in order to solve their livelihood problems. But the remaining 40 percent (119) of the respondents indicated that they had not received any credit from any institution during their lifetime. Those respondents who did have access to a credit system were asked to indicate the sources from which they had accessed their credit.

As presented in Figure 2, about 45percent of the respondents replied that they had obtained credit services from micro-financing institutions and also about three percent had received credit from commercial banks. This means that less than half of the interviewed population had accessed credit services from official or formal financial institutions in the study area. As such, concerned bodies should work strictly on creating awareness in rural communities as to the benefits that could accrue to them through the activities of formal financial institutions that provide credit services for rural communities. Instead of this, the credit beneficiaries would have serious problems in repaying loans. According to the rules of the financial institutions, anybody who has not repaid a previous loan would not have access to take out a second loan. The majority of credit beneficiaries stated that they considered the money was given to them as a gesture of support, but that the financial institutions, such as the microfinance and commercial banks, wanted the money to be repaid. However, the study determined that on account of the livelihood problems in the study area, the rural householders were not able to pay back their loans.

Contrary to this, about 52 percent of respondents replied that they had used the credit services of informal institutions as in the case of local money lenders $(21.5 \%)$, from relatives $(19 \%)$ and from friends $(12.2 \%)$ in the study area (Figure 2). These practices have their own deleterious side effects relating to the return of credit, that impact on the rural people's lives. If they do not return the money timeously to these groups, the result might be conflicts and the complete loss of their property, including their land, to the credit providers. During the focus group discussions, senior peasants said that some of their neighbouring households had lost their land because of credit-return-related problems and had become landless. In fact, some of the cases had actually gone to court. Thus, local government and formal financial institutions should work strongly to discourage informal credit sources and to find appropriate loan repayment methods for rural households in Wolaita zone.

As shown in Table 6, large numbers of rural communities in the study area were not habitually saving (56\%). The number of respondents who practised saving slightly differed from one study area to the other. For instance, in the Damot Pulasa woreda, about 47percent of the study population indicated that they were habitually saving as opposed to the 42percent in the Damot Gale woreda. Generally, in the Wolaita zone - particularly in the rural areas - the data show that 44 percent of the rural householders were practising saving.

Respondents who practised saving were also asked to indicate the institutions or informal places that they were using to accommodate their savings habit. As presented in Table 7, more than half of the respondents were using Omo Microfinance. The second way for saving was not via a modern financial institution but according to the traditional way of money saving which applies in many parts of Ethiopia and is called the Ikub system. Although this system is known to be an unsafe money management practice, 39 percent of the respondents used this system. Eight percent of the respondents saved money in their own houses which is also not a proper way of doing so. Only two percent were saving their money through an official banking system in the study area. The problem in this connection is that all of the commercial banking offices are situated in urban areas but that the larger part of the community lives in the rural areas. Therefore, all concerned bodies and professionals should work on a money-financing system for rural communities and for poorer people.

\subsubsection{Livestock Production}

Livestock production is the most important source of livelihood after crop cultivation for rural communities in the study area and at large. Animal rearing is a basic source for the rural households' protein-rich diet which is obtained from milk, milk products, and meat. Also, livestock have proved to be basic to the farming activities in the study area. However, the capacity to keep livestock in rural areas is determined by different natural factors such as animal diseases, the shortage of grazing land, environmental degradation, and drought. Under this section, the number of 
livestock kept by the study population was assessed in terms of the financial resources and the livelihood supports of the study population.

In study area rural communities were measured in terms of criteria to determine whether a household was livelihood secure or not. Of these criteria, the first one is ownership of a number of oxen for farming activities and milk cows to support the household's family through the provision of milk and milk products. A rural householder keeping less than three livestock units/ cattle, would be considered as livelihood insecure. From this point of view, the number of livestock kept by each rural household in the study area was presented in Table 8. As the data show, only 16 percent of the study population responded as they reared more than three cattle in their households. Fiftynine percent $(59 \%)$ of the study population had only one or two head of cattle at the household level. But 25 Percent of the study population replied that they had no cattle/livestock. Furthermore, farmers who said that they did not keep livestock and who indicated that they owned only one or two, were of the opinion that the main problem was a shortage of grazing land for cattle on account of farmland expansion over time.

As presented in Figure 3, the second major reason for limited cattle rearing in the study area was environmental degradation (28\%). Another minor cause was the fear of animal disease. As a result of these factors, the number of livestock kept by the sampled rural population was diminishing in size with time. This implies that a currently large number of rural farmers lacks one of the important financial resources, namely animal rearing, because of the rapid population growth and environmental degradation in the Wolaita zone.

\subsubsection{Income Levels of Households}

Assessing the income level of rural households is one of the better alternatives to measure the financial capital of the study population. All of the economic activities of the individuals are measured in terms of the daily or monthly income rate of the person. In this regard, the rural households in this study were asked to indicate their daily income levels according to four categories.

According to the World Bank Report of 2014, the poverty line for Ethiopia at the time was below 1.90US\$ per day and, based on this threshold, about 30 percent of the country's population was living below the poverty line. As per the data presented in Table 9, 52 percent of the daily income of the rural households was under the category of 10 to 15 Ethiopian birr or half a dollar (US) per day. This implies that the study population's daily income status was the worst in the even in comparison with the national figure.

Table 9, also shows that more than nine percent (9.7\%) of the study population earned 21 to 25 Ethiopian birr and above and 13.7percent earned 16 to 20 Ethiopian birr per day. Almost 77 percent of the study population's daily income was below one US, a serious consideration the light of the current exchange rate of the Ethiopian currency with the US dollar. In fact, the devaluation of the Ethiopian currency in terms of the international hard currency exchange rate has caused the price of imported items too sky-rocket, thus making the purchase of agricultural inputs such as fertilizer and insecticides very difficult. Thus increments in the daily income levels of the rural communities over time would be made valueless in the context of these problems.

To sum up, financial assets in terms of the daily income of the rural households in the study area were found to be very limited. This could be due to the effect of poor physical capital assets such as the small landholding size, infertile soils, the shrinking land size with the progress of time, the low vegetational coverage, the limited levels of human capital, and the poor credit and saving practices of the rural households.

As such, many of the rural householders have been faced with food security and livelihood security problems in the study districts and in the Wolaita zone generally.

\section{CONCLUSION}

The study revealed the major livelihood assets of the study area were categorized into three broad capital aspects, namely human, natural and financial. The lion's share of the source of labour for the rural households was family labour $(76.3 \%)$ from the human capital aspect. Only 3.3 percent of the householder respondents used hired labour. This means that the majority of households in the study area depended on family labour to meet the labour requirements for their livelihood strategies.

From the physical capital aspect, land is the main economic asset of and livelihood sources for agrarian rural people but the size of the plots is so small proved to be serious problems in the study area. In the study area, nearly 44 percent of the rural households were found to possess farmland plots smaller than 0.25 hectares while 75 percent of the sampled farmers possessed plots that were smaller than one hectare.

Access to credit service providers and the practice of saving are good elements that contribute to and determine the financial capital status of the household head. From the total 300 surveyed households, about $60 \%$ of the respondents had received credit services from different financial institutions to mitigate their socio-economic problems. However, the remaining 40 percent had not been exposed to such a service. About 45 percent of the rural communities were using credit services from microfinance institutions, and only three percent were the recipients of those from commercial banks. This implies that a large number of rural societies in the study area had obtained credit services from informal financial institutions. Beside these, a large number of the rural households (56\%) did not practise saving. From the financial capital aspect, and owing to the low economic returns 
in rural areas, saving is not a popular practice in the study area.

Livestock keeping is another source of financial capital in the study area. As the study shows, the number of livestock currently kept by individual households in the Wolaita zone has been minimized as a result of various manmade and environmental problems. As the surveyed data show, about $16 \%$ of the respondents indicated that they rear more than three cattle, 59 percent only one or two cattle per household and $25 \%$ stated that they have no cattle/livestock at the individual household level.

As the survey report for the daily income rate shows, 52 percent of the income of the rural households in the study area amounts to half a US dollar per day. This figure indicates that large numbers of the respondents were at or below the poverty level, were living food insecurity, and had livelihood problems. Thus, for rural households, their financial capital source has declined enormously and it is a highly dwindling livelihood situation that they have to deal with.

\section{REFERENCES}

Chambers, R. and Conway, G. 1992. Sustainable Rural Livelihoods: Practical Concepts for the $21^{\text {st }}$ Century. IDS Discussion Paper 296. IDS, Brighton, UK.

Deneke, D. 2008. Population Pressure and its Impacts on Food Security of Rural Households of Damot Woyde Woreda, Wolaita Zone. Published Thesis (MA). Addis Ababa University, Ethiopia.

FAO. 2004. Special Programme for Food Security Expands in Ethiopia. $</$ http://.fao.org/newsroom/>.

FAO. 2016. FAO's Country Programming Framework (CPF 2016 -2020) in Ethiopia. Online: $<$ /http://.fao.org/newsroom/> Accessed on 6/02/2019.

FAO. 2018. Food Security \& Nutrition around the World: 2018 the State of Food Security and Nutrition in the World. Online: <www.fao.org/state-of-food-security-nutrition/en/>Accessed on 11/04/2019.

Kgath D. L., Ngwenya B.N., Wilk J. 2007. Shocks and Rural Livelihoods in the Okavango Delta. University of Botswana, Botswana.

Mwassaa, W.M, 2012. Towards Livelihoods Security: Livelihoods Opportunities and Challenges in Embui, Kenya. Unpublished Master's Thesis submitted to University of South Africa, South Africa.

Swedish University of Agricultural Sciences (SLU), 2003. Rural Livelihoods: Current Issues In International Rural Development, Wikströms Tryckeri AB. Sweden.

Swift, J. 1998. Factors Influencing the Dynamics of Livelihood Diversification and Rural Non-farm Employment in Space and Time. Rural Nonfarm Employment Project, Chatham, Natural Resource Institute, UK.

Talemos, S. 2007. Diversity in 'Enset'-Based Home Gardens and its Significance to Household Food Supply in Wolaita Zone: Unpublished MSc Thesis. Addis Ababa University, Ethiopia.

Teferra, Z. 2009. State Sponsored and Self-initiated Resettlements: Their Impacts on the Ecology of Resettlement Areas (The case of Angar Gutin in Eastern Wallaga). In Svein Ege, Harald Aspen, Birhanu Teferra and Shiferaw Bekele(eds), Proceedings of the 16th International Conference of Ethiopian Studies, Trondheim.

Tegegne, S. 2014. Population Dynamics and its Impact on Land Use / Cover in Ethiopia: the Case of Mandura District of Metekel Zone, Benshangul-Gumuz Regional State. Unpublished PhD Dissertation submitted to University of South Africa, South Africa.

World Bank, 2011. World Development Indicators, Washington, D.C., USA

World Bank, 2016. World Development Indicators, Washington, D.C., USA

WZFEDD. 2018. Annual Statistical Abstract of 2018: Socio-Economic and Geo-spatial Data analysis and Dissemination Core Work. Wolaita Soddo, Ethiopia.

Table 1 Sources of Labour of Study Households

\begin{tabular}{lllllllll}
\hline \multirow{2}{*}{ Study Districts } & \multicolumn{3}{l}{ Sources of Labour of Respondents } & \multicolumn{3}{l}{ TOTAL } \\
\cline { 2 - 9 } & \multicolumn{3}{l}{ Through Family labour } & \multicolumn{2}{l}{ Through hired labour } & \multicolumn{2}{l}{ Both } \\
& No & \% of row & No & \% of row & No & \% of row \\
Damot Sore & 66 & 68.8 & 2 & 2.1 & 28 & 29.2 & 96 \\
Damot Gale & 71 & 79.8 & 3 & 3.4 & 15 & 16.9 & 89 \\
Damot Pulasa & 92 & 80 & 5 & 4.3 & 18 & 15.7 & 115 \\
& 229 & 76.3 & 10 & 3.3 & 61 & 20.3 & 300 \\
\hline
\end{tabular}

Source: Field survey, the Researcher (2018) 
Table 2 Educational Attainment of Household Heads

\begin{tabular}{|c|c|c|c|c|c|c|c|c|c|}
\hline \multirow[t]{3}{*}{ Study Woredas } & \multicolumn{8}{|c|}{ Educational Attainment of Household Heads } & \multirow[t]{3}{*}{ Total } \\
\hline & \multicolumn{2}{|c|}{ Illiterate } & \multicolumn{2}{|c|}{ Grades 1-8 } & \multicolumn{2}{|c|}{$\begin{array}{l}\text { Grades } \\
9-12\end{array}$} & \multicolumn{2}{|c|}{ Diploma \&above } & \\
\hline & No & $\%$ & No & $\%$ & No & $\%$ & No & $\%$ & \\
\hline Damot Sore & 49 & 51 & 24 & 25 & 15 & 15.6 & 8 & 8.3 & 96 \\
\hline Damot Gale & 32 & 36 & 19 & 21.3 & 26 & 29.2 & 12 & 13.4 & 89 \\
\hline Damot Pulasa & 42 & 36.5 & 37 & 32.5 & 21 & 18.3 & 15 & 13.1 & 115 \\
\hline Total & 123 & 41 & 80 & 26.7 & 62 & 20.7 & 35 & 11.7 & 300 \\
\hline
\end{tabular}

Source: Field survey, the Researcher (2018)

Table 3: Size of Landholdings prior to the 30, 20, and 10-years-ago and the Current Size of the Landholdings of the Study Population

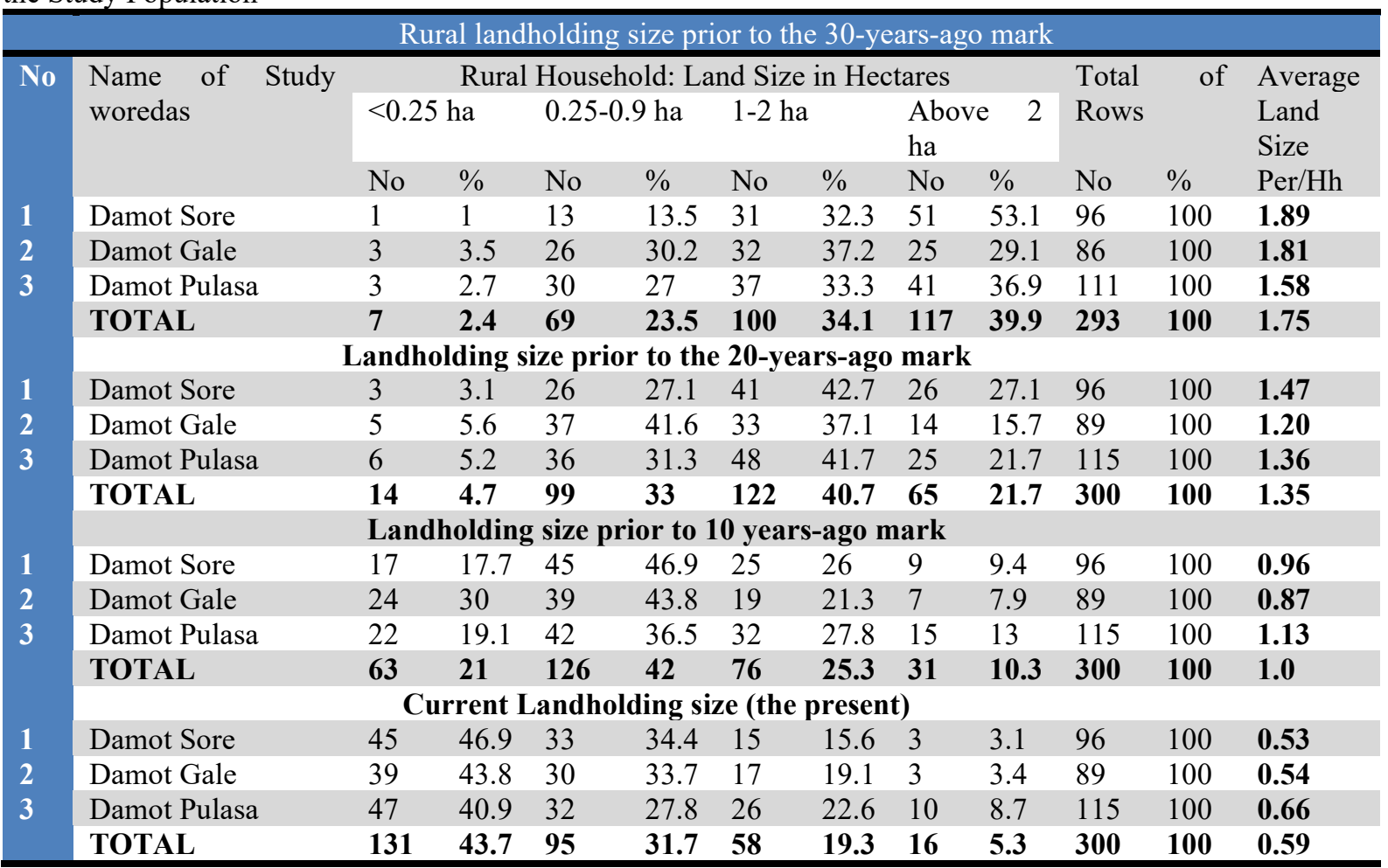

Source: Field survey, The Researcher (2018)

Table 4: Rural Householders' Perceptions about the Fertility of their Land

\begin{tabular}{|c|c|c|c|c|c|c|c|c|c|}
\hline \multirow[t]{3}{*}{ Study Woredas } & \multicolumn{8}{|c|}{ Perceptions by the Respondents of their Land Fertility Status } & \multirow[t]{3}{*}{ Total } \\
\hline & \multicolumn{2}{|c|}{ Infertile } & \multicolumn{2}{|c|}{ Moderately Fertile } & \multicolumn{2}{|c|}{ Fertile } & \multicolumn{2}{|c|}{ Very Fertile } & \\
\hline & No & $\%$ of rows & No & $\%$ of rows & No & $\%$ of rows & No & $\%$ of rows & \\
\hline Damot Sore & 46 & 47.9 & 17 & 17.7 & 21 & 21.7 & 12 & 12.5 & 96 \\
\hline Damot Gale & 43 & 48.3 & 11 & 12.4 & 19 & 21.3 & 16 & 18 & 89 \\
\hline Damot Pulasa & 55 & 47.8 & 22 & 19.1 & 31 & 27 & 7 & 6.1 & 115 \\
\hline TOTAL & 144 & 48 & 50 & 16.7 & 71 & 23.7 & 35 & 11.7 & 300 \\
\hline
\end{tabular}

Source: Field survey, the Researcher (2018)

Note: The fertility of the soil was not scientifically tested but reflects the perceptions of the rural communities. 
Table 5. Rural Households' Response towards Credit-Service Practices

\begin{tabular}{lllll}
\hline Study Woredas & Practice of Credit Services & Number & \% of Column & Total \\
\hline \multirow{2}{*}{ Damot Sore } & Practised & 57 & 59.4 & 96 \\
& Not practised & 39 & 40.6 & 89 \\
\multirow{2}{*}{ Damot Gale } & Practised & 54 & 60.7 & 115 \\
\multirow{2}{*}{ Total } & Not practised & 35 & 39.3 & 300 \\
& Practised & 70 & 60.9 & 39.1 \\
\hline
\end{tabular}

Source: Field survey, the Researcher (2018)

Table 6: Saving Habits of Respondents in the Study Area

\begin{tabular}{|c|c|c|c|c|}
\hline Study Woredas & Practice of saving & Number & $\%$ of Column & Total \\
\hline \multirow[t]{2}{*}{ Damot Sore } & Practised & 41 & 42.7 & \multirow[t]{2}{*}{96} \\
\hline & Did not practise & 55 & 57.3 & \\
\hline \multirow[t]{2}{*}{ Damot Gale } & Practised & 37 & 41.6 & \multirow[t]{2}{*}{89} \\
\hline & Did not practise & 52 & 58.4 & \\
\hline \multirow[t]{2}{*}{ Damot Pulasa } & Practised & 54 & 47 & \multirow[t]{2}{*}{115} \\
\hline & Did not practise & 61 & 53 & \\
\hline \multirow[t]{2}{*}{ TOTAL } & Practised & 132 & 44 & \multirow[t]{2}{*}{300} \\
\hline & Did not practise & 168 & 56 & \\
\hline
\end{tabular}

Source: Field survey, the Researcher (2018)

Table 7: Respondents' Saving Places/Institutions

\begin{tabular}{llll}
\hline No & Respondents' saving places/institutions & Number & \% of Columns \\
\hline 1 & Omo Microfinance & 69 & 52.3 \\
2 & Commercial Bank & 2 & 1.5 \\
3 & Own house & 10 & 7.6 \\
4 & Traditional or "Ikub" system & 51 & 38.6 \\
& Total & 132 & 100 \\
\hline
\end{tabular}

Source: Field survey, the Researcher (2018)

Table 8: Number of Livestock kept by Rural Households in the Study Area

\begin{tabular}{lllllllll} 
Study Woredas & \multicolumn{2}{l}{ Number of Livestock/Cattle for each Household } & \multicolumn{3}{l}{ Total } \\
\cline { 2 - 6 } & \multicolumn{2}{l}{ Three animals and above } & \multicolumn{2}{l}{ One to two animals } & \multicolumn{2}{l}{ No livestock } \\
& No & \% of row & No & \% of row & No & \% of row & \\
Damot Sore & 12 & 12.5 & 57 & 59.4 & 27 & 28.1 & 96 \\
Damot Gale & 14 & 15.7 & 53 & 59.6 & 22 & 24.7 & 89 \\
Damot Pulasa & 22 & 19.1 & 67 & 58.3 & 26 & 22.6 & 115 \\
Total & $\mathbf{4 8}$ & $\mathbf{1 6}$ & $\mathbf{1 7 7}$ & $\mathbf{5 9}$ & $\mathbf{7 5}$ & $\mathbf{2 5}$ & $\mathbf{3 0 0}$ \\
\hline
\end{tabular}

Source: Field survey, the Researcher (2018)

Table 9: Daily Income Levels for the Rural Households

\begin{tabular}{|c|c|c|c|c|c|c|c|c|c|}
\hline \multirow[t]{3}{*}{ Study Woredas } & \multicolumn{8}{|c|}{ Daily Income Level in Birr } & \multirow[t]{3}{*}{ Total } \\
\hline & \multicolumn{2}{|c|}{ 10-15Birr } & \multicolumn{2}{|c|}{ 16-20Birr } & \multicolumn{2}{|c|}{ 21-25Birr } & \multicolumn{2}{|c|}{26 Birr and above } & \\
\hline & No & $\%$ of Row & No & $\%$ of Row & No & $\%$ of Row & No & $\%$ of Row & \\
\hline Damot Sore & 53 & 55.2 & 22 & 22.9 & 9 & 9.4 & 12 & 12.5 & 96 \\
\hline Damot Gale & 55 & 61.8 & 18 & 20.2 & 6 & 6.7 & 10 & 11.2 & 89 \\
\hline Damot Pulasa & 48 & 41.7 & 34 & 29.6 & 14 & 12.2 & 19 & 16.5 & 115 \\
\hline Total & 156 & 52 & 74 & 24.7 & 29 & 9.7 & 41 & 13.7 & 300 \\
\hline
\end{tabular}

Source: Field survey, the Researcher (2018) 


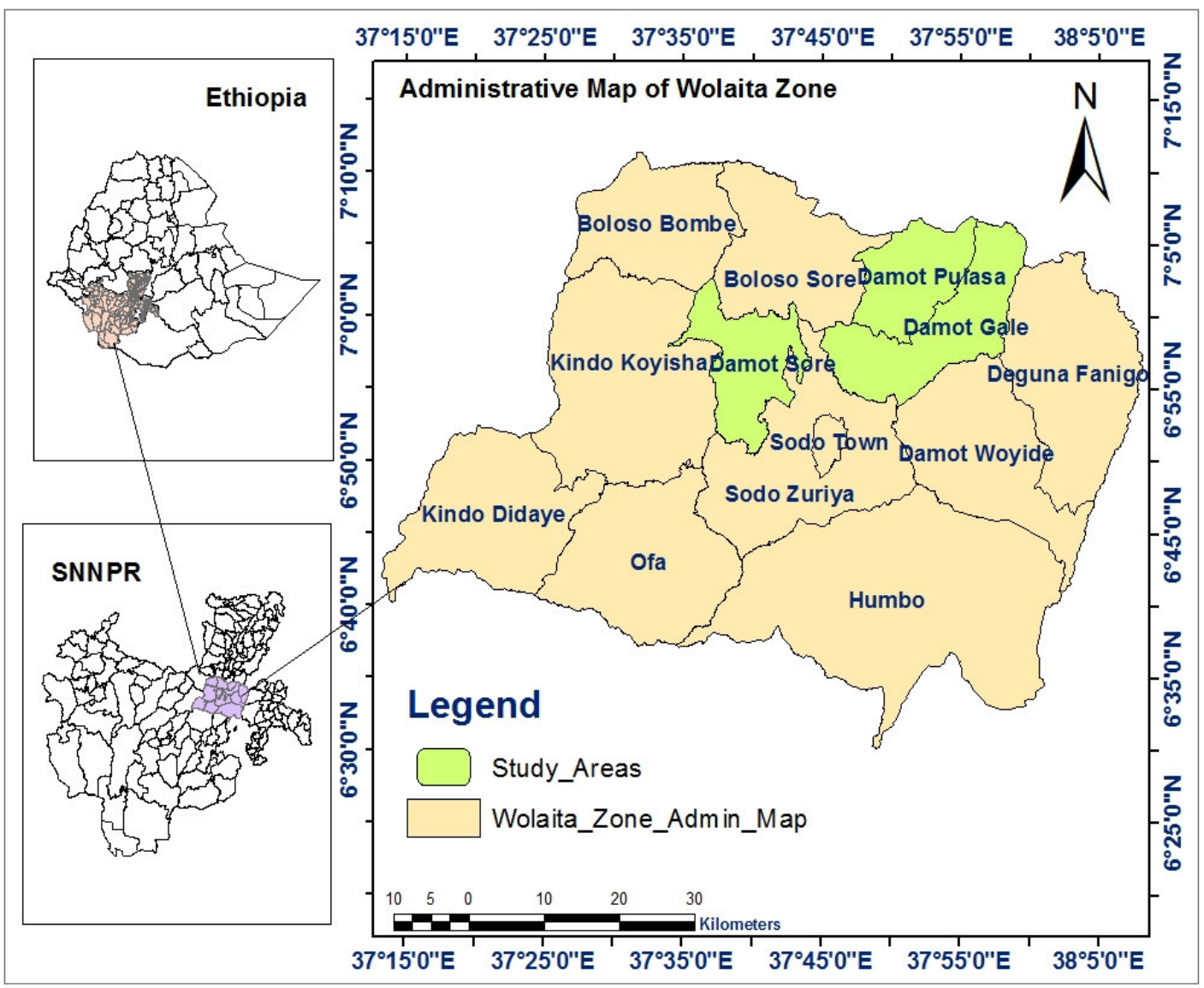

Figure 1: Map of the Study Area

Sources: Adopted from Ethio-GIS, 1999; CSA, 2007

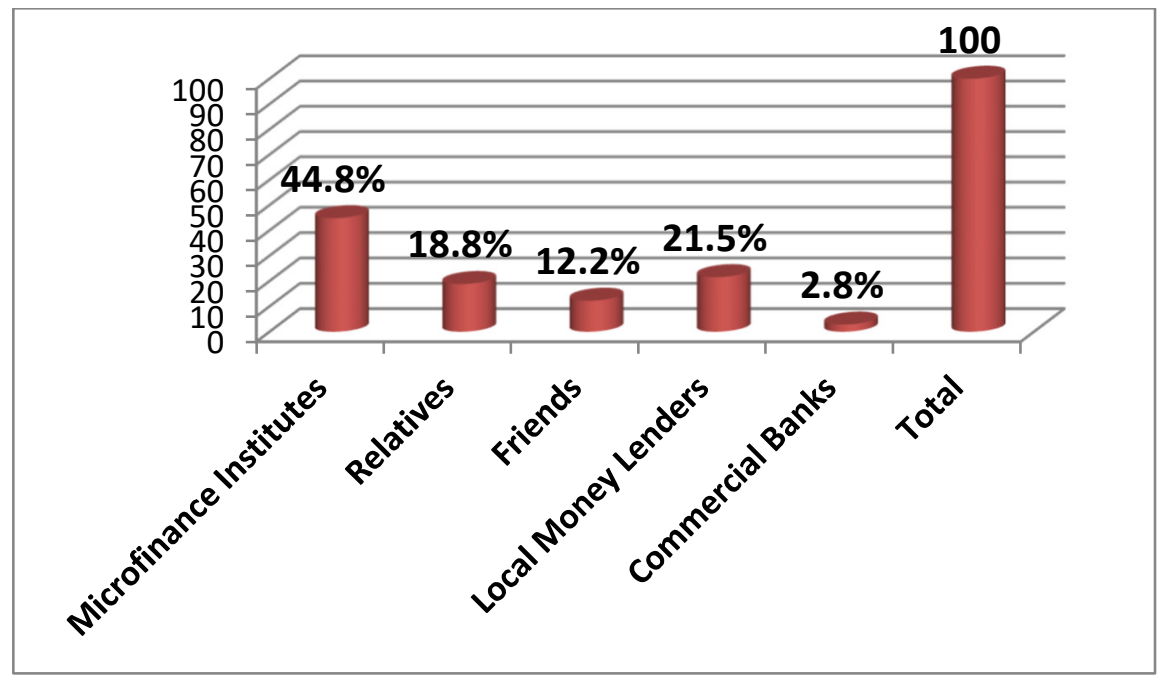

Figure 2: Sources of Credit Services for Respondents

Source: Field survey, the Researcher (2018) 


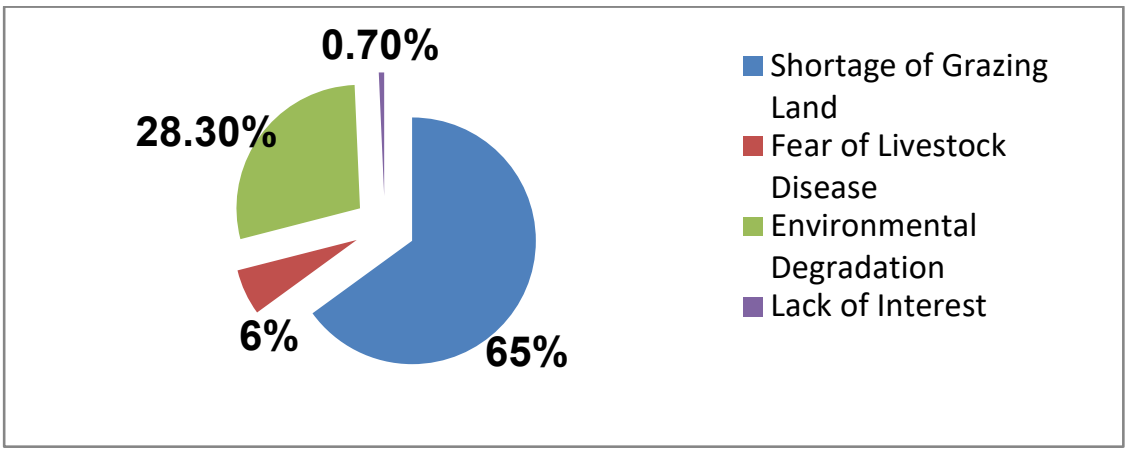

Figure 3: Reasons for the Ownership of a Small Number of Livestock Source: Field survey, the Researcher (2018) 